\title{
Discretion of Morality (Pancasila Moral Relations in The Laws of Political Determination)
}

\author{
Muhammad Aziz Zaelani $^{\text {I(corresponding author), I Gusti Ayu Ketut Rachmi Handayani }}{ }^{2}$, Isharyanto $^{3}$ \\ ${ }^{1}$ Universitas Sebelas Maret Surakarta, Indonesia; zael.aziz@ gmail.com \\ ${ }^{2}$ Universitas Sebelas Maret Surakarta, Indonesia; ayu_igk@staff.uns.ac.id \\ ${ }^{3}$ Universitas Sebelas Maret Surakarta, Indonesia; isharyanto_fh@staff.uns.ac.id
}

Submitted: December 17, 2019 - Revised: January 21, 2020 - Accepted: January 27, 2020 - Published: January 31, 2020

\begin{abstract}
This study has purpose to determine the form of Pancasila moral relations as the legal ideology of Indonesia in guarding discretion amid political determination. In this study, the conceptual approach was used as a basis for thinking to guide answe tor the problem which then analyzed using qualitative approach. The results showed that Pancasila as the ideology of Indonesian law is able to guard discretion in the form of moral relations that are reflected in discretion users. The implication, it is necessary to optimize the interpretation of the Pancasila in Law Number 30 of 2014 concerning Government Administration to realize the ideals of justice in the bureaucracy as per the Pancasila insight. Therefore, Pancasila morals can guard the use of discretion in political determination.
\end{abstract}

Keywords: Pancasila; discretion; moral

\section{INTRODUCTION}

The purpose of the Indonesian state in the Preamble of the 1945 Constitution of the Republic of Indonesia has given consequences for the Government to achieve it. The scope of these national goals indicates Indonesia as a welfare state ${ }^{(1)}$. As a state of law (rechtsstaat) ${ }^{(2)}$, The government must be based on law in carrying out its function as the holder of governing power ${ }^{(3)}$. Legal certainty must be held as the basic reference. On the other hand, justice and expediency must also be realized by the state to achieve legal objectives in addition to fulfilling legal certainty. Therefore, the fulfillment of legal certainty, in practice the administration of the state needs to be accommodated in the value of justice and usefulness so that it is in line with the basic legal value which is the goal of the law itself.

The fact that the dynamics of society in practice always moves and changes faster than the dynamics of law. This then implies a difference in motion between lawmaking and issues that develop in society. Therefore, in the conception of welfare state, government actions in certain matters can take action freely based on the principle of freies Germany, namely the legal authority to intervene in social activities to carry out the tasks of carrying out public interests. Expansion of the exercise of discretion by re-understanding the principle of freermany ermessen as the government's right to use its initiatives in the form of freedom of action to resolve concrete and urgent problems in society. In this case another problem occurs, namely the legal paradigm always has a classic problem if politics is more determinant than law. This led to public opinion that the law is controlled by the political elite. The formation of legal products must be full of configurations or political interests that accompany it $^{(4)}$. In fact, law and politics have the nature of mutual determinants and influence each other, there are even times when politics are determinants of law, so law is a political product ${ }^{(5)}$. This reality makes law as a political domain, up to its concretisation in normalizing the legislation including the use of discretion.

Discretion is an individual decision or action when effective restrictions on the power of government free him to make choices based on the possible necessity of acting or not acting for the benefit of the community (public good) without prescription of the laws and regulations, and even possible to deviate from the legislation applicable $^{(6)}$. The great authority of discretionary users opens a new paradigm that the law is prone to politicization. Coupled with the practice of Regional Autonomy as one of the forums for fulfilling the authority of Regional Heads as subjects who take care of their own government affairs in their regions gives a new color to government policies and actions taken including the use of discretion.

The results are expected to provide information on the form of Pancasila moral relations as the legal ideology of Indonesia in guarding discretion amidst political determination. This is aimed at multiplying the meaning of discretion as executive power in a bureaucracy that is in line with the Pancasila insight.

With the creation of a Pancasila-oriented bureaucracy including its power to use discretion, the law can protect itself from the determination of political interests and create social justice as the goal of the nation of the Indonesian nation. 


\section{METHODS}

This study applied a conceptual approach in exploring the morality of Pancasila as a legal ideology as the basis for the use of discretion. This study was a doctrinal law research. The conceptual approach was carried out when the researcher does not move from the existing legal rules. Researcher applied a conceptual approach need to explore the principles of law that can be found from the viewpoint of scholars or legal doctrines ${ }^{(7)}$. In this approach, the concept of law can also be found iand legislation. But researchers must first understand the concept through the views and doctrines that exist.

\section{RESULTS}

Discretion regulated in Law number 30 of 2014 concerning Government Administration. In the practice, there is still confusion in the implementation of discretion that causes confusion in the practical realm. Confusion in the practical domain has led to the issuance of a Presidential Instruction:

Presidential Instruction of the Republic of Indonesia Number 1 Year 2016, 9 January 2016, Regarding the Acceleration of the Implementation of the National Strategy Project, the President of the Republic of Indonesia instructed to: (1) the Working Cabinet Ministers; (2) Attorney General R.I; (3) National Police Chief R.I; (4) Cabinet Secretary; (5) Chief of Staff of the President; (6) Heads of Non-Ministry Institutions; (7) Governors; (8) The Regents/ Mayors, to provide support for the acceleration of the implementation of the National Strategic Project in the form of, among others: a. improve governance and improve the function of the Government Internal Oversight Apparatus in the context of overseeing the development of the National Strategic Project; $b$. Prioritize the government administration process in carrying out examination and settlement of reports of abuse of authority in the implementation of the National Strategic Project; c. Attorney General R.I prioritizes the process of government administration in accordance with the provisions of Law Number 30 of 2014 concerning Government Administration before conducting an investigation of public reports concerning the abuse of authority in the implementation of the National Strategic Project Instruction.

Instructions are aimed at law enforcement officials so as not to criminalize Discretion. The government noted that many officials were convicted of corruption cases including 8 Ministers, 19 Governors, 2 Governors of Bank Indonesia, 5 Deputy Governors of Indonesia, 40 Members of the Republic of Indonesia DPR, 150 Members of DPRD, and around 200 Regents/ Mayors. The data, according to the President, has implications for officials' fear in making decisions and/ or actions due to unclear definition of corruption and the rampant criminalization of policies and administrative procedures that are less clear and transparent, as a result the costs to be borne by the government are very large, namely the slow development due to state apparatus make decisions. Government capital expenditure has only reached 20 percent of the state budget and regional funds have settled in banks at 283 trillion. To overcome this, the President considered it important to use discretion to accelerate the implementation of development ${ }^{(8)}$.

Understanding Presidential Instruction No. 1 of 2016, can be seen from two perspectives: (i) The Presidential Instruction exists to protect and advance the interests of the state in terms of accelerating development in the implementation of national strategic projects. In this case demanding flexibility from the government in carrying out its functions including the use of discretion so that it calls on law enforcement officials not to criminalize discretion. (ii) The Presidential Instruction is a tangible manifestation of political determination of the law, in this case political interests are blending in and becoming the President's cause. The relationship between politics and the law can be seen from the beginning, starting from the view of positivists that the law is the command of the ruler, and its conflict with the historical school which views the law not only in terms of rules, but reality in society. Mahfud M.D, stated that the real law is a political product so that it is loaded with political interests that color it. In line with the opinion of Satjipto Rahardjo, who views the law as a result of the political process ${ }^{(4)}$. Thus, the legal position is always coupled with politics, because the relationship does influence each other.

The law is not autonomous, the law can not stand alone without the influence / factors outside the law, such as economic, political, social and cultural factors and even morality. Parsons places law as one of the subsystems in the larger social system ${ }^{(9)}$. Instead of law, there are other sub-systems that have different logic and functions. These sub-systems are political, economic and cultural. The various factors outside the law are to maintain the form of ideal patterns of a society. The law is placed as a media that occupies the role of the rule of the game. The function of factors outside the law is then to maintain and coordinate and control all forms of irregularities to conform to the rules of the game. In Talcott Parsons Cybernetics, political factors are closely related to power and authority, so they are transformed into a means of utilizing power and authority to achieve a goal $^{(8)}$. Interestingly, political factors are also influenced by economic factors being a means of utilization that 
refers to the material resources needed to sustain the life of the whole system. Cultural factors more reflect the acceptance or elasticity of society and control of the rules of the game.

\section{DISCUSSION}

Discretionary authority is actually intended to accelerate the realization of people's welfare. It is rooted in ermessen, namely the legal authority to interfere in social activities to carry out the tasks of carrying out public interests $^{(10)}$, therefore, it is expected to create effective and efficient means in the form of governmental functions to realize welfare in accordance with the concept of the welfare state. On the other hand, discretionary users in addition consist of career elements (which go through the ASN career path), consisting of political elements. As an example, a regional head is determined through an election mechanism, this position results in a close relationship between the regional head and the party supporting him, this situation is augmented by elements who are credited with accommodating the interests of the regional head during the campaign and election process. This makes a political determination that will structurally influence policy including the use of discretion.

Facing this form of political determination becomes difficult. As a concretisation of the election results that intersects with political elements, the Regional Head is responsible for the people who elect him. On one hand, it is impossible for the Regional Head to be separated from the political will of the supporting party, and other elements that support, support or assist the Regional Head to be elected. The assistance referred to is diverse and certainly has a certain purpose in the framework of including the interests of these supporting elements. The Regional Head becomes the risky object of being a victim of political determination, and the criticism will affect the policy and direction of the government to deviate from the corridor of public welfare. It is not uncommon for the Regional Head to become a prisoner because it is felt to be caused by political determination against him, so that inevitably the Regional Head collides with interests that demand fulfillment as a "reciprocation" of those who are responsible for, carry out, and support him first.

This flow makes it risky to use the authority of the state apparatus including the use of discretion so as to create bureaucratic diseases. This happens considering that in the top structure of the state administration, it is led by officials elected through political mechanisms so as to cause a vortex of political currents that drag the political will bureaucrats into the execution of administrative policies. The state administrator is vertically bound to the leader who creates a feudalistic pattern with no intended political determination.

The use of discretion which is actually closely related to the wisdom (wisdom) of its users, can be reflected with moral values. The author tries to instill a moral relationship with the law which in this paper means that discretion is a law rooted in the wisdom of its users. Hart also reflects the influence of morality on law (the influence of morality on Law). The law in every modern country shows thousands of points of morality that are accepted by society as well as broader moral ideas. This influence then pervades the law significantly. Many things show how the law reflects morality. Such things is the fact, which means the stability of the legal system depends in part on its form of conformity with morals and its existence must be recognized ${ }^{(11)}$. Then, it also needs to be criticized how this conclusion is related to the theory that separates law from morality. Law and morals are different, the law is interpreted as the text of the law, while morals refer to the highest principles of good or bad human actions or behavior ${ }^{(12)}$. Although not similar, but the Normative Jurisprudence, sees a relationship between the law and moral ideas in a systematic way ${ }^{(12)}$. The relationship between law and morals (Conceptual Connection Between Law and Morality) is very determined pattern of view of the source of law including the adoption of morals into positive law.

Indroharto believes that discretion is a form of freedom to determine wisdom or freedom to make a judgment which is good, not good, and which assessment is right and not right. In the implementation of discretion, two patterns are found, namely: (i) Freedom to judge objectively, if the norms in the law are vague but are actually intended as objective legal norms, because the explicit formulation is difficult to give, for example: the formulation behave as a servant of a good country; and, (ii) the freedom to judge subjectively, meaning that there is freedom to conduct one's own policy, because in this case the law has given authority to public officials to determine for themselves what should be done when facing a concrete event or problem ${ }^{(13)}$.

Understanding wisdom requires further consideration, while the policy includes the rules that are in it ${ }^{(14)}$. Policies that have entered the field of legal life, the formulation must also be subject to the techniques of making legislation that will be outlined or stated in the form of regulations must meet certain criteria. The way the formulation is carried out through legislation is to make hypothetical formulations ${ }^{(15)}$. Discretion is a formula that is carried out when the policy cannot run properly or there are obstacles that threaten the policy's objectives in its implementation. Therefore, discretion is always carried out spontaneously, rooted in Germany who demanded the initiation (emphasis on wisdom) of the government in solving the pressing problems of the community. The author assumes new discretion arises when the policy does not work well in the realm of 
practice. Discretion essentially shows a tendency in the form of an exception to having to act in accordance with general rules of the legislation (rule-based approach or rule following) ${ }^{(6)}$. The level of doctrine concludes in principle, it cannot test a free authority, as long as the free authority in its use does not: (i) conflict with the public interest; (ii) creates a conflict of interest; and, (iii) not bypassing or violating the power of civil agreements $^{(16)}$.

The fact that discretion must require a means of control because of the political element of those who use it. To be able to realize this, it is necessary to explore the function of Pancasila as the ideology of Indonesian law. The function of the Pancasila will be manifested by the following conceptual formulation:

First, Pancasila must be affirmed its position as a legal ideology. The Indonesian legal system that is guarded by Pancasila as its legal ideology. A nation's philosophy is synonymous with desires, the character of its people. It is impossible to take the philosophy of another country to become the philosophy of the nation just like that because all aspects of national life must be in accordance with the philosophy ${ }^{(17)}$. Savigny, constructs a theory about the existence of an organic relationship between law and the character or character of the nation. True law is not made but must be found in the soul of the people/ nation (volkgeist). The issue of managing the law is not artificially forming principles and doctrines, but finding principles and doctrines in living legal values by delving into the core of the soul of the people. ${ }^{(9)}$. The legal purpose paradigm is based on the doctrine that the law must reflect the basic value of law ${ }^{(18)}$, then legal certainty becomes the main characteristic that must be harmonized. Pancasila is obliged to enter and inspire all legal rules in this country, therefore it is called legal ideology. Cotterrell defines ideology as an idea that influences an action or behavior. "Legal ideology can be thought of, then, not as legal doctrine itself but as forms of social consciousness-system's of values and cognitive assumptions-reflected in and expressed through legal doctrines. ${ }^{(19)}$. Ketut Rinjin, stated that Pancasila as the basis of the Indonesian state has three meanings and three levels, namely: (i) as a universal-abstract basis as stated in the Preamble to the 1945 Constitution of the Republic of Indonesia; (ii) as a guideline for the administration of a state which is generally collective in nature as stated in the Body of the 1945 Constitution of the Republic of Indonesia; and, (iii) as a guideline for the administration of policies specifically specific to the state as contained in laws, government regulations, presidential regulations, etc ${ }^{(20)}$.

Second, Pancasila must inspire the basic principle of the use of discretion because of its consequences as a legal ideology. This meant that Pancasila became the basic principle of the use of factual and comprehensive discretion. What is meant here is the General Principle of Good Governance (AUPB) must be sourced from Pancasila and reflect its reflection in the principles of discretionary use.

Third, the principle that has been inspired by Pancasila became the basis and test stone for the use of discretion. The principle of law is not always contained in legislation, because it is abstract. The notion of the principle of law as a principle of fundamental evaluation in a legal system is rediscovered in the works of many legal theorists. Paul Scholten ${ }^{(21)}$ for example, outlines (gives a definition) the principle of law as follows: "Basic thoughts, which are contained within and behind the respective legal system, are formulated in statutory rules and judges' decisions, which with regard to individual provisions and decisions can be seen as a translation."

It is clear from the definition above, the principle of law is said to be an abstract fundamental foundation and is located within and behind the legal system and therefore always goes hand in hand with the law itself. Paul Scholten's definition can also be interpreted that the principles of law embody a kind of own system, some of which belong to the legal system, but some of which remain outside it. According to Scholten, the principles of law are both in the legal system and behind it. In this case Scholten's mind is directed to the positive legal system $^{(21)}$. Therefore, this creates the conclusion that the principle of law is still seen as something that exists outside the written norms of statutory regulations. This role also acts as a function of control over the implementation of the legislation itself. The dual role that can be understood from the principle of law in contact with the positive legal system is related to the nature that characterizes the legal principle as a rule of judgment (waarderingsnormen). The principle of law expresses the value of the legal system because it functions as a rule of judgment, but only a part of the principle of law can be realized in positive law. As long as the value of a legal principle is embodied in the legal principles of a positive legal system, then the legal principle is within that system ${ }^{(21)}$.

The main function of the principle of law is to realize the size of values as much as possible in the rules of positive law and their application. However, realizing that measure of value completely in a positive legal system is impossible. The principle of law can function that way because it contains a measure of value. As a rule of judgment, the principle of law can realize the highest legal principle of a positive legal system. That is why legal principles are and function as the foundation of the legal system. The legal principle is too general in nature to be able to act as a direct guideline for acts not like the rule of law, therefore the legal principle must be concretized $^{(22)}$. The legislators form the rule of law, in which the legislators formulate rules of behavior. Furthermore, concretisation in the rules of this behavior occurs through the generalization of the decisions of judges. If the concretisation has taken place and has been established (formed) positive legal rules and decisions; 
then the legal principle still has the nature as a rule of judgment, with that the legal principle comes to the surface $^{(9)}$. The measurement of the value given by the legal principle is difficult to realize fully, because the legal principle can still be faced with a positive legal system and serves as a critical test stone (kritische toetssteen). Therefore, every statutory regulation is obliged to make the legal principle as a guideline and in it embodies the values of the legal principle. At any time the principle of law can function as a touchstone against the legislation that is not in accordance with the principle of law.

Pancasila-oriented discretion is expected to be able to provide a reference to freedom based on government initiatives in taking action to deal with pressing problems in society. The action must reflect the values of Pancasila. In this case the implication is that Grundnorm in the form of Pancasila plays a role as a test of the validity of positive law.

In fact, Pancasila as the foundation of the state both substantively and morally provides an illustration of the boundaries used as a reference in keeping the administration of government in its tracks. These limits are the upper and lower limits. In this case the upper limit is intended to further interpret the nature of Pancasila as a moral and state foundation. The moral basis in question is the manifestation of the principle of the Almighty God by the analogy of implementing discretion must emphasize moral responsibility to God Almighty. Law basically has a relationship with morality, as Hart's opinion reflects the influence of morality on the law (the influence of morality on Law). The law in every modern country shows thousands of points of morality that are accepted by society as well as broader moral ideas. This influence then pervades the law significantly. Many things show how the law reflects morality. Such is the fact, which means the stability of the legal system depends in part on its form of conformity with morals and its existence must be recognized ${ }^{(23)}$.

In line with this, the law must be guided by morality, related to the exercise of discretion, aimed at creating discretion that has the axis of morality as a guide. In other words, morals become a legal guidance corridor that is implemented by legal subjects. Moral becomes a human guide in every activity of his life, which gives to truth according to the ratio. Aristotle described the core of humanity as rational morality, which views truth (theoria, contemplation) as the primacy of life (summum bonum) ${ }^{(23)}$.

The next reflection, discretion must be able to embody the value of humanity that is fair and civilized. Justice as it is at the core of such civilized humanity, provides a benchmark that must be achieved by the discretion maker. Then the resulting discretion must fulfill the sense of justice which is actually directed at the people. Justice itself implies several meanings. Gustav Radbruch has the most interesting content regarding his definition related to the role of justice, which is placed as a legal ideal (Rechtsidee), which has the same position as Grundnorm Kelsen's description which both presuppose norms or values that go beyond and are above the positive legal order. The difference here is that the contents of Rechtsidee have been determined in a limitative way, that is, advancing the goodness of human life which is a measure for the fair or unfair legal system ${ }^{(12)}$.

The Fair and Civilized Precepts of Humanity, also emphasizes the dignity of human beings. Man was created by God Almighty with a set of rights that guarantee his degree as a human being summarized in Human Rights. In this case the position as a state of law (rechtstaat) is recognized as a regulatory framework to guarantee human rights in the form of ensuring the interests of justice for all people. Every person has the right to his right to justice. Thus, the developed legal state is not an absolute rechtsstaat but a democratic rechtsstaat ${ }^{(24)}$. Discretion is expected to be able to open up space to solve pressing problems in society while upholding human rights as a form of recognition of the dignity and human dignity within the scope of Fair and Civilized Humanity.

Discretion must also reflect the value of unity and cohesion. In this paradigm, discretion must still be guided by the public interest. As is the case in the rules of making rules, it should not be contrary to public interests, not contrary to norms in society, so that it can create rules that have behavior and have legitimacy in the form of recognition from the community itself.

The value of democracy as stated in the People's Principles, Led by Wisdom Wisdom in Representative Consultation. The democracy adopted in Indonesia is a democracy based on Pancasila. Thus the Indonesian democracy implies that in addition to general values special values are demanded. Indonesian democracy is populistism, led by wisdom in the deliberative deliberations. In this case the government must uphold the conception of the people, by the people and for the people. Discretion as a form of government initiative in carrying out its functions must be able to manifest as an amplifier of democracy based on democracy.

Finally, as a goal, discretion must fulfill the objective of social justice for all Indonesian people. Justice referred to here is massive in the form of social justice. It needs to be understood this is closely related to the concept of welfare state that makes people's welfare as the main goal. Moving on from the Pancasila reflection set forth in the Preamble of the 1945 Constitution of the Republic of Indonesia. Coupled with the aim of "creating public welfare" is considered to be the cause of the welfare state. This is sufficient to describe the government's obligation to achieve prosperity in the form of Social Justice for All Indonesian People. Then the discretion must be in line with the concretisation of this value which in the course of the discretion is expected 
to be present and able to be a concise and ideal means for the government to overcome problems in achieving the country's goals.

\section{CONCLUSION}

Pancasila as the ideology of Indonesian law can oversee the use of discretion by way of; upholding the position of Pancasila as the ideology of Indonesian law, Pancasila must infiltrate every legal product in Indonesia, and Pancasila must inspire the principles used in discretion. Pancasila is reflected in the use of discretion, then discretion must be in line with the concrete values of Pancasila, namely God, humanity, unity, society and social justice. With the fulfillment of these values, discretion is expected to be present and able to become a concise and ideal means for the government to overcome problems in achieving the country's goals.

\section{REFERENCES}

1. Muchsan. Supervision of the Acts of the Government Apparatus and State Administrative Court (Pengawasan terhadap Perbuatan Aparatur Pemerintah dan Peradilan Tata Usaha Negara. Yogyakarta): Liberty; 1992.

2. Asshiddiqie J. Introduction to Constitutional Law (Pengantar Hukum Tata Negara). Jakarta: Rajawali; 2010.

3. Lotulung PE. Public Papers Principles of Good Governance (AAUPB) (Himpunan Makalah Asas-Asas Umum Pemerintahan yang Baik (AAUPB)). Bandung: Citra Aditya Bakti; 1994.

4. Sulaiman KF. Indonesian Legal Politics (Politik Hukum Indonesia). Yogyakarta: Thafa Media; 2017.

5. Mahfud MD. Legal Politics in Indonesia (Politik Hukum di Indonesia). Jakarta: Rajawali Press; 2012.

6. Darumurti KD. Discretionary Study of Legal Theory (Diskresi Kajian Teori Hukum). Yogyakarta: Genta Publishing; 2016.

7. Marzuki PM. Legal Research (Penelitian Hukum). Jakarta: Kencana; 2005.

8. Kompas. Jokowi Request for a No-Criminal Policy ("Jokowi Minta Kebijakan Jangan Dipidana) [Internet]. Kompas. 2018.Available from: http://m.republika.co.id/beri-jokowi-minta-primary policy

9. Bernard L, Tanya BL, et. all. Legal Theory of Orderly Human Strategy across Spaces and Generations (Teori Hukum Strategi Tertib Manusia Lintas Ruang dan Generasi). Yogyakarta: Genta Publishing; 2010.

10. Hadjon PM. Administrative Law and Good Governance (Hukum Administrasi dan Good Governance). Jakarta: Universitas Trisakti; 2010.

11. Safa'at MA. Legal Concepts of H.L.A Hart (Konsep Hukum H.L.A Hart). Jakarta: Constitution Press; 2016.

12. Atmadja IDG. Legal Philosophy of Thematic and Historical Dimensions (Filsafat Hukum Dimensi Tematis dan Historis). Malang : Setara Press; 2013.

13. Indroharto. State Administrative Court (Peradilan tata Usaha Negara). Jakarta: Pustaka Sinar Harapan; 1993.

14. Suandi IW. The Existence of Public Policy and in the Implementation of Regional Government (Eksistensi Kebijakan Publik dan Dalam Penyekenggaraan Pemerintahan Daerah). Journal of Social Sciences. 2010;1(1):12-13.

15. Rahardjo S. Legal Studies (Ilmu Hukum). Bandung: Alumni; 1986.

16. Manan B. Fair State of Law (Negara Hukum yang Berkeadilan). Bandung: FSKN FH UNPAD; 2011.

17. Huda N. Indonesian Constitutional Law (Hukum Tata Negara Indonesia). Jakarta: Rajawali Press; 2005.

18. Ali A. Revealing the Secret of Law (Menguak Tabir Hukum). Jakarta: Chandra Pratama; 1996.

19. Cotterrell R. The Sociology Of Law: An Introduction; 1992.

20. Winarno. Pancasila Education in Higher Education (Practical Guide to Learning) (Pendidikan Pancasila di Perguruan Tinggi (Panduan Praktis Pembelajaran)). Surakarta: Yuma Pustaka; 2012.

21. Sidharta A. Reflections on Law (Refleksi Tentang Hukum). Bandung: Aditya Bakti; 1995.

22. Mertokusumo S. An Introduction to the Law (Mengenal Hukum Suatu Pengantar). Yogyakarta: Liberty; 2003.

23. Tanya BL. Law Enforcement in the light of Ethics (Penegakkan Hukum Dalam Terang Etika). Yogyakarta: Genta Publishing; 2011.

24. Sinal M. Pancasila Indonesian Consensus Pancasila (Pancasila Konsesnsus Bangsa-Bangsa Indonesia ). Malang: Madani; 2017. 